\title{
The help relationship in clinical nursing education
}

\author{
Ernestina Silva ${ }^{a *}$, Maria Lucinda Maia ${ }^{b}$, Daniel Silva $^{a}$, Amarilis Rocha $^{a}$, \\ João Duarte ${ }^{\mathrm{a}}$ \\ * Corresponding author: Ernestina Silva, ernestinabatoca@sapo.pt, +351232419100; fax: +232428343 \\ ${ }^{a}$ Superior Health School, Polytechnic Institute of Viseu, Rua D. João Crisóstomo Gomes de Almeida, $n^{\circ}$ 102, 3500-843 Viseu, \\ Portugal \\ ${ }^{\mathrm{b}}$ Hospital Baixo Vouga, EPE, Av. Artur Ravara, 3814 Aveiro, Portugal
}

\begin{abstract}
http://dx.doi.org/10.15405/epsbs.2016.07.02.12

The clinical nursing education involves considerable effort from students. They established interpersonal relationships and they are active participants in this process. What is the perception of nursing students and the parents of the children in the help relationship (HR) developed during the clinical training were some of our research questions. We aimed to identify factors that influence interpersonal relations between nursing students and the mothers of hospitalized children; analyze the relationship between the perspective of students and the parents of the children on the HR developed during the clinical training; identify feelings experienced by students and parents in the relational process of care taking. As methods quantitative, descriptive and correlational study, conducted in a sample of 139 nursing students and 73 mothers of hospitalized children. It was used a questionnaire, which includes socio-demographic, training and clinical characterization and the BarrettLennard Relationship Inventory (BLRI), which evaluates the help relationship in four dimensions have been used. The dimensions of help relationship - Level of Regard, Empathic Understanding and Unconditionally Respect - are scored positively by students and mothers. The Congruence of performance is evaluated negatively by mothers while students are evaluated positively. Prevailing negative feelings referenced by students and the positive feelings by mothers. The perception of help relationship is influenced by some socio-demographic variables of students and mothers. All dimensions establish a dependent relationship with the group of students and mothers. The perception of students on the HR is positive, the perception of mothers regarding student performance is also positive, except in Congruence.
\end{abstract}

CC 2016 Published by Future Academy www.FutureAcademy.org.uk

Keywords: Nursing care; help relationship; nursing students.

\section{Introduction}

Nursing training, traditionally carried out based on a biomedical model, has been the object of several studies which have enabled a significant evolution in their conception. There is special interest cc) (i) $\Theta$

This is an Open Access article distributed under the terms of the Creative Commons Attribution-Noncommercial 4.0 Unported License, permitting all non-commercial use, distribution, and reproduction in any medium, provided the original work is properly cited. 
in designing a caring practice, underlying a holistic view of the individual, a singular focus of the nursing practice. Caring is definetly the core of the Nursing profession, being considered an art and science, which encompasses human and scientific know-how based on interpersonal relationships (Ferreira, Pontes, \& Ferreira, 2009). As mentioned by Watson (2002) and Lopes \& Jorge (2005), it is increasingly clear that there is an awareness that nursing training must assist the individual on the whole, as well as acknowledge that learning is subjective, built on the context and guided by values. Training for caring purposes requires a significant personal effort on the student's part, as well as from their mentor and clients themselves, so that they can gradually build a heritage of skills and abilities enabling them to identify what they intend or need to develop, where and how they can act.

In Portugal initial training in Nursing presupposes the guarantee of acquisition of professional skills which meet the legal Framework of the Statutes of the Ordem dos Enfermeiros (Law no. 156/2015 of 16th September) and the skill profile required by the Ordem dos Enfermeiros $(2003,2012)$. This skill profile divides them into three domains: professional, ethical and legal practice; care provision and management; professional development. It is precisely the domain of care provision and management which includes valuation of communication and interpersonal relationships in the therapeutic relationship with the client and/or caretakers, family and community, as well as in the relationship with other professionals, valuing the roles and abilities of all. An effective clinical communication is associated with patient satisfaction, adherence, health outcomes and job satisfaction (Bachmann and others, 2013). In this sense, it is essential that the curricula of the several educational establishments cover contents and conducts exploring and nurturing this peculiar domain, so difficult to perfect, and associate them with professional practice.

Lazure (2007) finds that, in order to materialize a care relationship, the nurse must have skills/abilities such as listening skills; help in clarifying, which requires being accurate and concrete; self-respect and respect for others; congruence regarding oneself and other; confronting oneself and others; being empathetic with oneself and with others.

In order to define help relationship, we turned to Phaneuf (2005), who regards it as being a particularly significant relationship, established between a person who is experiencing a problem, suffering and struggling to handle it alone, and a helper (a nurse in this case), who helps them facing it at a given moment and finding the necessary resources to deal with it within themselves. Chalifour (2008) mentions that the help relationship is based on a singular interaction between two persons, the professional and the client, in which both contribute to the pursuit and fulfillment of an assistance need expressed by the client and attended to by the nurse which suits their way of being and communicating with a view to achieving their goal. The therapeutic relationship established individuals who seek help bringing their own life experiences, know-how obtained, personal values, beliefs and drive to change into the relationship, whereas nurses bring their experience, understanding and skills.

Besides scientific know-how and methodological skills, personal and interpersonal skills are essential to student's training; these kind of skills, as stated by Peixoto and others (2012), can and must be acquired, trained and perfected, stimulating the student to develop a set of strategies and abilities which enable a flexible response. Nevertheless, we know that it is not always easy to combine and convey the whole essence of the profession and there are paradoxes and conflicting messages along the 
http://dx.doi.org/10.15405/epsbs.2016.07.02.12

eISSN: 2357-1330 / Corresponding Author: Ernestina Silva

Selection and peer-review under responsibility of the Organizing Committee of the conference

training path covered by nursing students. In some cases we witness the diffusion of messages that practice (real life) does not apply knowledge on which (ideal) training is focused. In this sense, it is important that nursing training includes a formative model with a correlation between theoretical training and experience in a working context, uses a common language, in an attempt to improve care quality and bring the real world closer to the ideal world, always thinking and rethinking the nurse's mission according to the human being as a whole, as a focus of care.

In pediatrics, caring presupposes not only involving the child according to their age and development, but also the person who represents and follows them along this path, and it is important to consider these clients through the voice of their parents, who are strongly represented as minders of children, as well as reflect on their expectations: what they carry with them, which thoughts and feelings they keep to themselves. All of us endure things to a given limit. Parents of hospitalized children certainly have different thresholds, undermined by the shadow of diagnosis and prognosis, anguish or simply the interruption of the balance in the daily routine which stretches the moment indefinitely. As depicted by Escoval \& Candoso (2000, p.34), "the hospital is an organization for care provision, but it is also a social institution in our society. It occupies a position which is similar to that of the church or school and is part of symbolic representations of individuals (...)”.

It is essential to reflect on the process of development of clinical education in pediatrics and their implication in clinical practice quality. We acknowledge the importance of the help relationship and became interested in exploring the way in which caretakers and care receivers interpret nursing care during clinical education provided to pediatric nursing students.

The focus on the perspective of the parents of children is pondered and intentional, given that they also observe and analyze nursing practices, and thus hold information which they truly experienced and which are likely to bring significant subsidies for the constant perfecting of the nurse's mission as, according to the Kalamazoo II Report, patients may be the best judges of effectiveness of interpersonal skills of health care professionals (Duffy and others 2004). On the other hand, Branch and others (2001) mention that perhaps the best way for an individual to learn abilities and behaviours is to practice them, be monitored, receive useful feedback, reflect on their performance and repeat the cycle subsequently.

We are also interested in hearing nursing students, given that their training implies performance and action in the context of clinical practice which presupposes direct participation in nursing care and the relationship with the parents of children.

Our study was oriented by the following research questions: What is the perception of nursing students on the help relationship provided to the parents of children during clinical training? What is the perception of the parents of children on the performance of the help relationship provided by nursing students during clinical training? What is the relationship between the perception of nursing students and the parents of children on the help relationship during clinical training?

In an attempt to obtain answers to the questions raised, we set as goals: identifying the perception of nursing students on the help relationship developed with the parents of children in their clinical training in pediatrics; identifying the perception of the parents of children on the performance of the help 
relationship provided by nursing students in the care process; comparing the perception of nursing students and the parents of children on the help relationship developed during clinical training.

\section{Methods}

Quantitative, descriptive and correlational study which is aimed at describing and explaining the help relationship established by nursing students, in their own perspective and in the perspective of the mothers of hospitalized children.

A non-probability sampling was carried out, being composed of 139 nursing students from two health schools in the central region of Portugal who were performing clinical training in pediatrics at pediatric inpatient and emergency services/OUs, as well as by 73 parents of said children. Information of the study's purpose was provided and they agreed to participate in an enlightened way and willingly. We obtained permission from the corresponding chairmen of institutions following a favourable opinion from the Ethics Committees. Data collection was performed in person and took place between February and July 2014.

The data collection instrument was a questionnaire covering the Barrett Lennard Relationship Inventory (BLRI) (Barrett-Lennard, 1986) in two versions: Myself to Other (MO - 40 items) for nursing students and Other to Self (OS - 40 items) for the parents of hospitalized children. The questionnaire was translated into Portuguese by Paula (2012) and validated for Portuguese population in a study with nurses (MO with an overall Cronbach's alpha coefficient of 0.87 and of 0.75 in our study) and Gonçalves (2013) in a study with mothers and female nurses in neonatology (OS with an overall Cronbach's alpha coefficient of 0.773 and of 0.883 in our study). It is composed of a systematized set of forty statements expressing experiences in interpersonal relationships and four dimensions of help relationship, equitatively distributed by a set of ten statements concerning the perception of the experienced relationship. Statements are organized in a positive or negative manner, as summarized in table 1:

Table 1. Dimensions and figures of items corresponding to MO-40 and OS-40.

\begin{tabular}{lcc}
\hline Dimensions & Positive statements & \multicolumn{1}{c}{$\begin{array}{c}\text { Negative } \\
\text { statements }\end{array}$} \\
\hline $\begin{array}{l}\text { Level of regard (tendency to an emotional reaction by one } \\
\text { individual towards another) }\end{array}$ & $1,5,13,21,29,37$ & $9,17,25,33$ \\
$\begin{array}{l}\text { Empathic understanding (recognition of the other } \\
\text { individual) }\end{array}$ & $2,10,18,26,34$ & $6,14,22,30,38$ \\
$\begin{array}{l}\text { Unconditionality of regard (level of constancy of a feeling } \\
\text { of respect by one individual towards another) }\end{array}$ & $7,15,27,39$ & $3,11,19,23,31$, \\
$\begin{array}{l}\text { Congruence (process involving the desire of being highly } \\
\text { committed to another individual, knowing their experience } \\
\text { and being able to receive their feeling) }\end{array}$ & $8,12,20,24,32$ & $4,16,28,36,40$ \\
\hline
\end{tabular}

Each statement is answered according to a scale in which participants can describe their relationship up to three points of view, presented in a sequence of six levels in which +3 corresponds to yes, considered as a strong agreement, and -3 corresponds to no, considered as a strong disagreement. The score of each of the four dimensions of this inventory (MO-40 and OS-40) may vary between -30 and 
http://dx.doi.org/10.15405/epsbs.2016.07.02.12

eISSN: 2357-1330 / Corresponding Author: Ernestina Silva

Selection and peer-review under responsibility of the Organizing Committee of the conference

+30 , in which the higher the score obtained, the higher the importance attached to the Help Relationship.

The instrument also includes questions aimed at characterizing participants as regards social, demographic, clinical and formative aspects, as well as describing feelings and experiences.

We used the 22.0 SPSS (Statistical Package for Social Science) software for data analysis.

\section{Findings}

Most students are female (81.3\%), with an average age of 21.87 years and a standard deviation of 2.906 years. Most of them live in a rural area $(53.2 \%)$ and $95.7 \%$ are single. As for their opinion on training in the help relationship, $61.2 \%$ mentioned that contents were provided during theoretical teaching $(76.6 \%$ at school $\mathrm{A}$ and $53.3 \%$ at school $\mathrm{B})$, without significant differences $(\mathrm{X} 2=7.130 ; \mathrm{p}=0.008)$. As regards the dimensions of help relationship assessed by the questionnaire, we observed that the average values for Level of regard are $16.67( \pm 5.69)$ and for Empathic understanding are $11.20( \pm 7.28)$, two dimensions which were well scored by students. As for Unconditionality of regard, the average score is $0.50( \pm 6.93)$ and in Congruence the average corresponds to $6.15( \pm 9.01)$, dimensions which received lower scores. Figures found coincide with other studies (Frade, 1999; Paula, 2012; Gonçalves, 2013), in which the lowest values of Unconditionality can be attributed to the fact that relationships are brief, given that the hospitalization period is short and students have little contact with mothers (sometimes only during an 8-hour shift).

As regards minders, these always correspond to the mothers of children, with an average age of 36.53 years $( \pm 4.831)$, living in an urban area $(80.8 \%)$, most of them married $(65.8 \%)$; in terms of their educational attainment, $46.6 \%$ have completed secondary education and $35.6 \%$ higher education, whereas $83.6 \%$ are working. The reason for hospitalization of the child mentioned the most was a medical condition (74\%) and the duration period mentioned by $41.1 \%$ was 1 or 2 days.

We sought to find out the way mothers obtained the information that there were nursing students in the service and $47.95 \%$ mentioned that they learned it by means of the observation of the uniform and identification card, $27.39 \%$ mentioned that it was the nurse who presented the student and $9.59 \%$ mentioned that the students presented themselves. We were also interested in learning whether consent for nursing students to provide care to children had been requested and observed that the highest percentage of mothers answered no (61.64\%).

As for the perception of mothers on the performance of the Help Relationship of nursing students and their dimensions in relational situations experienced, data from BLRI - OS-40 Form show an average of $19.86( \pm 6.25)$ for the Level of regard, an average of $7.56( \pm 10.48)$ for the Empathic understanding dimension, and an average score of $4.04( \pm 7.88)$ for Unconditionality of regard. In Congruence we verified a significantly low average of $-1.52( \pm 10.21)$. Almeida (2012), in a study on the perspective of parents on the help relationship in pediatrics, and Loureiro (2012), when studying the perspective of adolescents on the performance of the help relationship of nurses, observed similar findings for the Level of regard and Empathic understanding dimensions, but the lowest scores were found in the Unconditionality dimension. 
When comparing the perception of relational skills of help in the perspective of nursing students with parents of hospitalized children, over the course of clinical nursing education in pediatrics, we observed that mothers classified with higher values than students the Level of regard $(X=19.86 \pm 6.25)$ and Unconditionality of regard $(X=4.06 \pm 7.88)$ dimensions, while the reverse was true when it came to Empathic understanding $(X=11.20 \pm 7.27)$ and Congruence $(X=6.15 \pm .00)$, which were classified with higher scores by students. Differences between groups are highly significant in the Level of regard and Congruence dimensions $(\mathrm{p}=0.000)$ and very significant in the Empathic understanding and Unconditionality of regard $(\mathrm{p}=<0.005)$, and thus we infer that there is a dependence relationship between the two groups in all dimensions of the help relationship. These data suggest that mothers do not regard students as having a high level of engagement and may have doubts on their sincerity, genuineness and transparency. On the other hand, students positively perceive congruence, show integrity, consider themselves honest and consistent in terms of what they think and express. This mismatch of opinions can point to the apparent incoherence between feelings and behaviours, which may lead to a lack of trust on the part of mothers.

Barrett-Lennard (1986) enlightens that the figures obtained are not aimed at classifying levels of Help Relationship, but essentially learning the aspects with the greatest or lowest "need" of a given quality (regard, empathy, unconditionality of regard and congruence) in the individual or group. The same author mentions that it is highly unlikely to find similar outcomes in the different dimensions, given that they reflect distinct feelings, and the level of regard is usually the dimension with the highest averages - which we observed in our two samples -, whereas unconditionality has the lowest averages, verified in nursing students.

\section{Conclusions}

This study is aimed at identifying the perception of nursing students and mothers on the development of a help relationship during clinical training, in their mutual relational experiences. The sample included 139 nursing students under clinical training in pediatrics and 73 mothers monitoring children hospitalized in the pediatric unit. We used the BLRI questionnaire in the MO-40 and OS-40 Forms, which gather the dimensions of Level of regard, Empathic understanding, Unconditionality of regard and Congruence. The questionnaire showed a reasonable internal consistency in the MO-40 version (overall Cronbach's alpha coefficient of 0.75 ) and a satisfactory internal consistency in the OS40 version (overall Cronbach's alpha coefficient of 0.883 ).

As for the perception of nursing students on the help relationship developed with the parents of children in their clinical training in pediatrics, we concluded that they perceived a good performance of the help relationship in the development of clinical training in pediatrics, but the unconditionality of regard fell short of our expectations.

In the perception of the mothers of children on the performance of the help relationship of nursing students in the care process, they showed that mothers have a high perception on nursing students in terms of the level of regard. Nevertheless, we verified that the empathic understanding dimension has lower levels than those expressed by students and congruence has negative values, data which suggest 
that the help relationship may be insufficient in this aspect and that congruence needs to be further worked on.

Perceiving that one is congruent is not showing a conflict between what one thinks, feels and expresses. In our view, the student's perspective presupposes consistent attitudes, built on the principle that their performance covers an interpersonal relationship of help, but they can have incoherent attitudes in the development of their role.

As the help relationship is an essential pillar of care in nursing, training of students must involve the development of relational skills of help and tools enabling them to develop quality nursing care. In a holistic perspective of care regard for feelings and coherence in attitudes and conducts must be promoted, given that it will improve the trust and approval of mothers.

We suggest the creation and stimulation of groups of reflection with teachers, students and nurses of the practice, facilitating the expression of difficulties, emotions, fears, as well as clarifying notions and methods of action which are consensual and may contribute to develop good practices in clinical training.

We also propose a proper integration of mothers into services, explaining procedures and methods, enabling the expression of opinions and feelings without prejudice or judgment, assessing the needs in order to promote the acceptance of students in care provision.

As we are aware that we only developed a valid study in its specific context, in which perceptions, experiences and feelings of each individual are unique and subjective, it is impossible to generalize outcomes.

\section{Acknowledgements}

The authors acknowledge with gratitude the patience and contribution of students and mothers for children in hospital.

\section{References}

Almeida, E. (2012). Relação de ajuda em pediatria: Perspetiva dos pais. Master's thesis in Child Health Nursing and Pediatrics. Viseu: Escola Superior de Saúde de Viseu.

Barrett-Lennard, G. (1986). The relationship inventory now: issues and advances in theory, method, and use. IN The psicotherapy process: a research handbook. New York: Guilford. pp. 439- 475

Branch WT, Kern D, Haidet P, et al. (2001). Teaching the Human Dimensions of Care in Clinical Settings. JAMA, 286:1067-1074.

Bachmann, C. et al. (2013). A European consensus on learning objectives for a core communication curriculum in health care professions. Patient Education and Counseling 93, 18-26.

Chalifour, J. (2008). A Intervenção Terapêutica: Os fundamentos existencial-humanistas da relação de ajuda. Loures: Lusodidacta

Duffy, F.D., Gordon GH, Whelan G, et al. (2004). Assessing competence in communication and interpersonal skills: the Kalamazoo II Report. Acad Med,79:495-507.

Escoval, A., \& Candoso, F. (2000). Níveis Intermédios de Gestão nas Instituições de Saúde. In: Proença, J. et al (2000). O Hospital Português: Os Profissionais de Saúde, A Gestão e o Utente. Porto: Vida Económica. Conferforum.

Ferreira, M., Pontes, M., \& Ferreira, N. (2009) Cuidar em Enfermagem - Perceção dos utentes. Revista da Faculdade de Ciências da Saúde. Porto: Universidade Fernando Pessoa. Available in http//bdigital.ufp.pt/bitstream/10284/1288/1/358-66_FCS_06_.pdf.

Frade, J. (1999). Relação de ajuda em enfermagem: Perspetiva sobre a prática e a formação. Master's Dissertation in Nursing Science. Porto: Instituto de Ciências Biomédicas Abel Salazar. 
eISSN: 2357-1330

Selection \& Peer-review under responsibility of the Conference Organization Committee

Gonçalves S. (2013). Relação de ajuda em neonatologia: Perceção das mães e das enfermeiras. Master's thesis in Child Health Nursing and Pediatrics. Viseu: Escola Superior de Saúde de Viseu.

Lazure, H (2007). Viver a relação de ajuda. Abordagem teórica e prática de um critério de competência da enfermeira. Lisboa: Lusodidacta.

Lopes, C., e Jorge, M. (2005). Interacionismo simbólico e a possibilidade para o cuidar interativo em enfermagem. Revista Escola Enfermagem USP. 39(1), pp. 103-108.

Loureiro, H. (2012). Cuidar em enfermagem: Perceção do adolescente. Master's thesis in Child Health Nursing and Pediatrics. Viseu: Escola Superior de Saúde de Viseu.

Ordem dos Enfermeiros (2003). Competências do(a) enfermeiro(a) de cuidados gerais. Revista da Ordem dos Enfermeiros. No 10 , pp. $49-56$

Ordem dos Enfermeiros (2012). Regulamento do perfil de Competências do enfermeiro de cuidados gerais. Ordem dos Enfermeiros. Available in: http://www.ordemenfermeiros.pt/publicacoes/Documents/divulgar\%20$\% 20$ regulamento\%20do\%20perfil_VF.pdf

Paula, T. (2012). Relação de ajuda: Perspetiva do enfermeiro de pediatria. Master's thesis in Child Health Nursing and Pediatrics. Viseu: Escola Superior de Saúde de Viseu.

Peixoto, A. et al. (Coord. Cardoso, R.M.) (2012). Competências clínicas de comunicação. Porto: Artes Gráficas, Lda.

Phaneuf, M. (2005). Comunicação, entrevista, relação de ajuda e validação. Loures: Lusociência.

Watson, J. (2002). Enfermagem: Ciência Humana e Cuidar. Uma Teoria de Enfermagem. Loures: Lusociência.

Portugal. Assembleia da República. Decree-Law No. 156/2015 of 16th September - Second amendment to the Statutes of the Ordem dos Enfermeiros. Diário da República [Portuguese official gazette] no. 181, I Series A, p.8059-8105 